PLPB: Pendidikan Lingkungan dan Pembangunan Berkelanjutan

DOI: https://doi.org/10.21009/PLPB.181.01

DOI: 10.21009/PLPB

\title{
HUBUNGAN ANTARA POLA ASUH DAN KONSEP DIRI DENGAN PERILAKU LINGKUNGAN MAHASISWA
}

\author{
Agus Priadi \\ Program Studi Administrasi Perkantoran \\ Akademi Sekretaris dan Manajemen BSI Jakarta \\ email: agus.agp@bsi.ac.id
}

\begin{abstract}
The objective of this research was to understand comprehensively about the child's perception towards parents' parenting and self-concept with responsibility environmental behavior on college students of academy of management and secretary of BSI in Central Jakarta. It was a quantitative research conducted in a private educational academy in Central Jakarta. The data were collected through participant observation using questionnaire. The data searched by the researcher use correlational approach with survey technique. The data analysis and interpretation indicates that (1)the correlation between child's perception towards parent's parenting and responsibility environment behavior on college students are positive and significant with the result of correlation is 0,327.(2) the correlation between self-concept and responsibility environment behavior on college students are positive and significant with the result of correlation is 0,360. Some efforts which have to be done by parents dealing with child's perception towards parenting are keep communicating with children as many as possible frequently, put trust well on them doing their lives, keep controlling by distance so that parents still understand what they are doing outside, etc. Regarding to self-concept there are many ways to be given to students such as giving training, counselling, put confidence on them, giving them skills well, etc.
\end{abstract}

Keywords: child's perception towards parents' parenting, self-concept, responsibility environmental behavior. 


\section{Pendahuluan}

Masalah lingkungan menjadi sorotan dan fokus utama dalam perkembangan dunia sekarang ini. Lingkungan identik dengan kehidupan manusia dan ada hubungan yang sangat erat antara ekologi dengan manusia. Hubungan tersebut diwujudkan dengan perilaku dan sikap yang positif terhadap lingkungan. Perilaku yang demikian akan memunculkan perilaku masyarakat yang berwawasan lingkungan.

Perilaku

berwawasan

lingkungan sangat penting dalam kehidupan manusia sebagai bagian dari ekosistem. Selain sebagai bagian dari ekosistem, manusia juga sebagai subyek karena pada dasarnya merupakan pengelola dari sistem tersebut sehingga keseluruhan perubahan-perubahan yang terjadi di dalam daerah lingkungan hidupnya merupakan hasil dari perilaku manusia. Sejalan dengan hal itu Chiras (1988:76) mengatakan bahwa perilaku manusia sebagai pengelola sistem yang hidupnya didasarkan pada sifat dasar yang dikenal dengan "Biological Imperialism" yakni sifat yang mau makan untuk hidup bagi dirinya dan keturunannya. Sifat ini menimbulkan mentalitas frontier yang mempunyai anggapan bahwa bumi mempunyai sumber tak terbatas, manusia mencari keuntungan sebesar-besarnya, manusia dapat menguasai alam, menganggap selalu ada jalan keluar pada setiap permasalahan yang dihadapi. Jika manusia terus menerus dapat memenuhi kebutuhan materi, kehidupannya akan lebih baik.

Sifat dasar manusia inilah yang menimbulkan masalah lingkungan yaitu perubahan-perubahan yang diakibatkan oleh perbuatan manusia. Dengan makin banyaknya jumlah manusia disertai dengan kebutuhannya yang makin meningkat serta semakin meningkat pula tingkat kemampuan manusia untuk melakukan intervensi terhadap alam lingkungannya, perubahan yang terjadi dalam lingkungan juga akan semakin besar. Perubahanperubahan yang semakin besar tersebut akan mengganggu fungsi ekologi alam terhadap kesejahteraaan hidup manusia, baik secara nyata maupun potensial, dampak inilah yang menjadi masalah lingkungan global yang sangat dirisaukan sejak puluhan tahun yang lalu.

Pengaruh-pengaruh perilaku manusia terhadap lingkungan hidupnya tersebut di atas telah menimbulkan berbagai masalah lingkungan. Perilaku manusia tidak hanya sekedar perilaku masyarakat secara umum saja, melainkan banyak melibatkan organisasi, kelompok dan individu seperti pemerintah (birokrasi), Lembaga Swadaya Masyarakat (LSM), perguruan tinggi, sekolah, masyarakat, maupun pemuda.

Seperti diketahui, masalah lingkungan bukan hanya sekedar masalah individu manusia itu sendiri, tetapi telah meluas menjadi masalah nasional maupun internasional (Hayati, 2001:5). Masalah lingkungan seperti terjadinya kebakaran di mana-mana, timbulnya berbagai penyakit akibat kualitas kesehatan yang kurang baik dan masalah-masalah sampah yang tidak terkendali, banjir dan erosi, tanah longsor sampai pencemaran udara, air dan tanah. Kemudian isu efek rumah kaca yang telah meningkatkan suhu global yang mampu memindahkan daerah-daerah produksi pertanian, menaikkan 
permukaan laut sehingga membanjiri kota-kota pantai dan merusak ekonomi berbagai bangsa. Sedangkan perkembangan industri telah mengancam terjadinya kerusakan lapisan ozon yang melindungi planet bumi, sehingga pada tingkat tertentu akan mengganggu rantai makanan dan meningkatnya penyakit kanker pada manusia dan hewan akibat radiasi sinar $\mathrm{x}$ dari matahari.

Berbagai tanggapan tentang kerusakan lingkungan sebagai akibat perilaku, muncul sebagai peertanda bahwa masalah lingkungan sudah mengkhawatirkan kehidupan manusia. Pada umumya mereka berpendapat bahwa kerusakan lingkungan merupakan resiko dan bahaya besar yang akan dihadapi umat manusia. Kekhawatiran tersebut bertambah karena kenyataan menunjukkan bahwa laju pertumbuhan penduduk yang cukup tinggi telah menimbulkan kepadatan penduduk yang tinggi pula dan tentunya akan semakin meningkatkan terjadinya perusakan lingkungan hidup guna tujuan pemukiman maupun mencari nafkah.

Demikian pula halnya dengan kondisi sosial masyarakat kota Jakarta saat ini. Kota-kota identik dengan perkembangan industri yang demikian pesat. Perkembangan industri yang demikian besar yang didorong oleh arus urbanisasi dan pertumbuhan penduduk yang semakin cepat, menimbulkan berbagai persoalan khususnya dengan penyediaan lapangan pekerjaan dan kerusakan lingkungan. Dalam hal ini, dituntut peran dan partisipasi masyarakat yang positif dalam menyikapi persoalan lingkungan. Dalam kaitan dengan masalah tersebut, peran pemuda dan remaja dalam hal ini mahasiswa-mahasiswi ASM BSI sebagai tulang punggung pembangunan dituntut lebih besar lagi. Perilaku hidup yang semakin modern berkaitan erat dengan masalah lingkungan membutuhkan sikap dan perilaku remaja yang bersahabat dengan lingkungan. Perilaku lingkungan tersebut diwujudkan dengan kegiatankegiatan yang berkaitan dengan lingkungan. Kegiatan pemeliharaan lingkungan dapat dimulai dari lingkungan terkecil yakni lingkungan tempat tinggal dan sekolah.

Penduduk dalam lingkungan terkecil perlu memahami dan menganalisis kondisi lingkungan. Demikian pula halnya dengan peran para mahasiswa, remaja dan pemuda yang ternyata mempunyai peranan penting dalam pengelolaan lingkungan dan pembangunan. Oleh karena itu, partisipasi mereka dalam pembangunan berkelanjutan menjadi sangat penting. Peran remaja dalam hal ini mahasiswa-mahasiswi ASM BSI dalam mengelola lingkungan bermula dari kehidupan pada lingkungan keluarganya termasuk pola asuh yang diberikan oleh orang tuanya. Kegiatan-kegiatan yang dapat dilakukan antara lain membersihkan halaman rumah, kebersihan lingkungan, menanggulangi sampah, pemanfaatan MCK (mandi, cuci, kakus) secara baik. Pembenahan limbah rumah tangga dan kegiatankegiatan lain yang berkaitan dengan pengelolaan, pemeliharaan, pelestarian, dan pemanfaatan lingkungan dilakukan secara efektif dan efisien.

Dasar dari penyesuaian diri bagi individu adalah kesadaran akan diri dan lingkungan. Kesadaran akan diri mengacu pada gambaran tentang diri dan penilaian pada diri sendiri. 
Sedangkan kesadaran terhadap lingkungan mengacu pada persepsi individu terhadap lingkungannya baik lingkungan sosial, non sosial, fisik maupun psikologis. Peranan konsep diri bagi individu dalam berperilaku tidak dapat diragukan lagi, sebab konsep diri merupakan pusat dari perilaku individu. Safarino menjelaskan bahwa konsep diri adalah pemikiran seorang tentang ciri khas dirinya yang meliputi ciri-ciri fisik, jenis kelamin, kecenderungan, tingkah laku, watak emosional dan cita-cita. Berdasarkan deskripsi uraian di atas maka perilaku remaja menjadi sangat penting dalam mengelola lingkungan yang selaras dengan tuntutan hidup mereka. Oleh karena itu, diupayakan agar lingkungan tetap dapat mendukung kehidupan yang berkelanjutan melalui pengembangan perilaku yang baru yakni perilaku lingkungan bagi remaja. Perilaku lingkungan harus ditingkatkan sehingga banyak hal yang tidak dapat diabaikan dalam upaya merubah dan meningkatkan perilaku remaja antara lain dengan meningkatkan pengetahuan remaja tentang lingkungan, meningkatkan pengetahuan tentang isu-isu lingkungan dan peraturan perundangundangan daerah mengenai lingkungan. Disamping itu perlu meningkatkan pemahaman, wawasan, persepsi, sikap, kesadaran dan kepedulian terhadap lingkungan.

Perilaku lingkungan bagi remaja tersebut seyogyanya didasarkan pada pengetahuan tentang lingkungan, kesadaran, kepedulian dan sikapsikap pada lingkungan serta kemajuan dan perkembangan wawasan berpikir individu. Berdasarkan pengetahuan dan kepedulian tersebut di atas, diharapkan perilaku lingkungan bagi remaja berwawasan lingkungan dapat timbul dalam aktivitas seharihari dalam membina keselarasan dengan lingkungan hidupnya. Hasil penelitian ini diharapkan (1) dapat memberikan gambaran tentang faktor-faktor yang berhubungan dengan pembentukan perilaku lingkungan pada mahasiswamahasiswi Akademi Sekretari dan Manajemen BSI di Jakarta Pusat, (2) mengembangkan wawasan penulis dan pengalaman berharga dalam melatih kemampuan penulis melakukan penelitian yang berkaitan dengan faktor-faktor yang berhubungan dengan pembentukan perilaku lingkungan pada mahasiswa-mahasiswi Akademi Sekretari dan Manajemen BSI di Jakarta Pusat, (3) menjadi data dasar untuk pengembangan penelitian selanjutnya.

Dalam banyak hal, kajian mengenai perilaku berkaitan erat dengan aspek-aspek kajian motivasi, sikap, pembelajaran dan bahkan pengetahuan seseorang. Hal ini disebabkan oleh adanya anggapan bahwa perilaku adalah refleksi dari arah seseorang dalam memberikan tanggapan dan tata cara bertindak (manner of behaving). Sesuai dengan sifat suatu persamaan dan elemenelemen perkalian yang terkandung di dalamnya, apabila tidak terdapat drive, maka ungkapan reaksi berupa perilaku tidak akan berfungsi meskipun terdapat latar belakang kebiasaan (habit) yang sangat kuat.

Konsep Hull (1943:129) mengungkap secara lugas adanya hubungan yang saling memperkuat antara kebutuhan dan dorongan yang bermuara kepada bentuk perilaku seseorang. Adanya kebutuhan mengarah kepada pembentukan suatu dorongan dan kemudian ditanggapi dalam wujud perilaku. 
Temuan Hull ini tidak berbeda jauh dengan konsep perilaku yang pernah dikembangkan oleh Icek dan Martin. Menurut kedua pakar ini perilaku memiliki empat elemen penting yaitu tindakan (action), target (target), konteks (context); dan waktu (time). Berdasarkan konsepsi Icek dan Martin tersebut, perilaku secara nyata ditunjukkan dengan adanya aksi atau tindakan tertentu untuk meraih target berupa keinginan atau tujuan dalam rangka memenuhi kebutuhan atau tujuan sesuai dengan kondisi dan dimensi waktu pada saat berlangsungnya perilaku tersebut. Oleh karena itu, menurut konsep dimaksud, perilaku tidak akan mencuat ke permukaan tanpa adanya faktor-faktor pencetusnya yaitu keempat elemen perilaku tersebut.

Sementara itu, dalam model psikologi klasik Sternberg $(2008 ; 58)$, konsep perilaku sangat dipengaruhi oleh tiga komponen esensial yaitu pengetahuan, kesadaran, dan tindakan. Dari konsep ini, diketahui bahwa perilaku seharusnya bernuansa positif sebab didukung oleh seperangkat pengetahuan dalam tingkat kesadaran tertentu yang akhirnya berwujud tindakan konstruktif. Pernyataan ini diperkuat oleh pandangan Bloom $(1981 ; 42)$ yang menyatakan sebagai berikut, perilaku seseorang dipengaruhi oleh kapasitas pengetahuannya dalam hal mengingat (remembering) kejadian masa lalu, memanggil kembali memori, dan menuangkan ide.

Berkenaan dengan konsep dan batasan perilaku yang telah diuraikan, dapatlah dinyatakan bahwa pengertian perilaku siswa yang sejalan dengan substansi penelitian ini adalah tindakan atau rangkaian aktivitas yang berlandaskan kepada kebiasaan, kesadaran, dan pengetahuan.
Penyebab berbagai gangguan yang terjadi di planet bumi berakar dari tabiat dasar manusia sebagai imperialis biologis di mana ia memerlukan makan dan berkembang biak, tanpa peduli keterbatasan sumber daya alam dalam menyediakan kebutuhan hidup bagi diri dan keturunannya. Kerusakan lingkungan merupakan manifestasi pengembangan dari permasalahan sosial dan lingkungan yang saling terkait.

Hal ini merupakan tantangan bagi pengembangan pendidikan lingkungan untuk dapat memberikan kontribusi terhadap pembentukan perilaku yang bertanggung jawab terhadap lingkungan hidup. Pendidikan lingkungan hidup merupakan pembelajaran yang dilakukan untuk membantu peserta didik dalam memahami lingkungan hidup dengan tujuan akhir untuk meningkatkan perlindungan dan sikap bertanggung jawab terhadap lingkungan hidup.

Pendidikan Lingkungan Hidup (PLH) merupakan aspek yang dapat memberikan perlakuan kepada peserta didik menuju kesadaran lingkungan. Hal ini penting karena permasalahan lingkungan yang ada merupakan hasil dari akumulasi perilaku manusia yang semakin krusial dan global. Selain itu, PLH merupakan salah satu langkah intervensi dalam pembinaan pembentukan perilaku yang bertanggung jawab terhadap lingkungan hidup.

Kerusakan alam yang terjadi pada dasarnya lebih dititikberatkan pada kemampuan manusia untuk melihat dengan jangkauan jauh melampaui batas kepentingan sendiri di samping kemampuan dalam melihat kenyataan yang sebenarnya dalam kehidupan (Soerjani, 
1997:19). Kerusakan lingkungan merupakan manifestasi pengembangan dari permasalahan sosial dan lingkungan yang saling terkait. Pengertian yang mendalam mengenai lingkungan alam merupakan isu sosial dan ekologis, sehingga krisis lingkungan dapat dikatakan sebagai hasil interaksi dari berbagai keprihatinan global (Van Rensburg dalam Soemarwoto, 1992:14).

\section{Dengan}

demikian, permasalahan lingkungan hidup tidak dapat dipecahkan secara teknis semata, namun yang lebih penting adalah pemecahan yang dapat mengubah mental serta kesadaran akan pengelolaan lingkungan. Hal ini merupakan tantangan bagi pengembangan pendidikan lingkungan untuk dapat memberikan kontribusi terhadap pembentukan perilaku yang bertanggung jawab terhadap lingkungan hidup. Meskipun memerlukan proses yang panjang, serta hasilnya tidak dapat dilihat dengan segera seperti halnya pemecahan secara teknis, namun melalui pembinaan perubahan perilaku ke arah lebih bertanggung jawab dalam pengelolaan lingkungan merupakan hal yang strategis (Hayati, 1999:10).

Persepsi merupakan suatu proses yang didahului oleh penginderaan, yaitu proses yang berwujud diterimanya stimulus oleh individu melalui alat reseptornya dan diteruskan ke pusat susunan syaraf yaitu otak, sehingga individu dapat mempersepsi apa yang ia lihat, ia dengar, dan sebagainya (Walgito, 1997: 7-10). Persepsi juga bisa dimaknai sebagai pengalaman tentang objek, peristiwa atau hubungan yang diperoleh dengan menyimpulkan informasi dan menafsirkan pesan (Rakhmat, 2001: $31)$.

Persepsi menurut Stenberg mendefinisikan sebagai seperangkat proses yang dengannya kita mengenali, mengorganisasikan, dan memahami cerapan-cerapan indrawi yang kita terima dari stimulasi lingkungan.

Davidoff (1998:

mengatakan bahwa dengan persepsi individu dapat menyadari, mengerti tentang keadaan lingkungan di sekitarnya dan juga tentang keadaan diri individu yang bersangkutan. Persepsi merupakan pandangan, pengamatan, atau tanggapan seseorang terhadap benda, kejadian, tingkah laku manusia atau hal-hal yang diterimanya sehari-hari.

Berdasarkan uraian tersebut dapat disimpulkan bahwa persepsi adalah proses diterimanya stimulus oleh individu melalui alat reseptornya dan diteruskan ke pusat susunan syaraf, sehingga individu dapat menyimpulkan informasi, menafsirkan pesan, menyadari, mengerti tentang keadaan lingkungan di sekitarnya dan juga tentang keadaan diri individu yang bersangkutan.

Menurut Walgito (1997: 1216) ada beberapa jenis persepsi yaitu: persepsi melalui indera pendengaran, persepsi melalui indera penciuman, persepsi melalui indera pengecap dan persepsi melalui indera kulit atau perasa.

Sedangkan menurut Irwanto (1997: 71) ada dua jenis persepsi yaitu: 1) persepsi positif, yaitu persepsi yang menggambarkan segala pengetahuan dan tanggapan yang selaras dengan objek persepsi yang diteruskan dengan upaya pemanfaatannya; 2) persepsi negatif, yaitu persepsi yang menggambarkan segala pengetahuan dan tanggapan 
yang tidak selaras dengan objek persepsi. Hal ini akan diteruskan dengan kepastian untuk menerima atau menolak dan menentang segala usaha objek yang dipersepsikan.

Intinya persepsi berasal dari panca indera, apabila persepsi tersebut selaras dengan pengetahuan maka hal tersebut dikatakan sebagai persepsi positif, akan tetapi jika objek persepsi tidak selaras dengan pengetahuan maka hal tersebut akan menjadi persepsi negatif.

Proses terjadinya persepsi yaitu adanya rangsangan dari luar, adanya kesadaran individu terhadap rangsang, individu menginterpretasi rangsang tersebut, dan mewujudkan dalam bentuk tindakan. Selain itu terdapat proses fisik, fisiologis, psikologis, dan hasil dari proses persepsi.

Setiap orang tua pasti menginginkan anaknya menjadi orang yang berkepribadian baik, sikap mental yang sehat serta akhlak yang terpuji. Orang tua sebagai pembentuk pribadi yang pertama dalam kehidupan anak, dan harus menjadi teladan yang baik bagi anakanaknya. Sebagaimana yang dinyatakan oleh Daradjat (1996:58), bahwa kepribadian orang tua, sikap dan cara hidup merupakan unsurunsur pendidikan yang secara tidak langsung akan masuk ke dalam pribadi anak yang sedang tumbuh.

Dalam mendidik anak, terdapat berbagai macam bentuk pola asuh yang bisa dipilih dan digunakan oleh orang tua. Pola asuh menurut Kamus Besar Bahasa Indonesia (1998:692), pola berarti corak, model, sistem, cara kerja, bentuk (struktur) yang tetap. Sedangkan asuh dapat berarti menjaga (merawat dan mendidik) anak kecil, membimbing (membantu; melatih dan sebagainya), dan memimpin (mengepalai dan menyelenggarakan) satu badan atau lembaga. Lebih jelasnya, kata asuh adalah mencakup segala aspek yang berkaitan dengan pemeliharaan, perawatan, dukungan, dan bantuan sehingga orang tetap berdiri dan menjalani hidupnya secara sehat.

Menurut Ahmad Tafsir seperti yang dikutip oleh Danny I. YatimIrwanto (1991: 94), Pola asuh berarti pendidikan, sedangkan pendidikan adalah bimbingan secara sadar oleh pendidik terhadap perkembangan jasmani dan rohani anak didik menuju terbentuknya kepribadian yang utama.

Jadi pola asuh orang tua adalah suatu keseluruhan interaksi antara orang tua dengan anak, di mana orang tua bermaksud menstimulasi anaknya dengan mengubah tingkah laku, pengetahuan serta nilai-nilai yang dianggap paling tepat oleh orang tua, agar anak dapat mandiri, tumbuh dan berkembang secara sehat dan optimal.

Anak membutuhkan dukungan dan perhatian dari keluarga dalam menciptakan karyanya. Karena itu, pola asuh yang dianggap lebih cocok untuk membantu anak mengembangkan kreativitasnya adalah otoratif atau biasa lebih dikenal dengan demokratis. Dalam pola asuh ini, orang tua memberi kontrol terhadap anaknya dalam batas-batas tertentu, aturan untuk hal-hal yang esensial saja, dengan tetap menunjukkan dukungan, cinta dan kehangatan kepada anaknya. Melalui pola asuh ini anak juga dapat merasa bebas mengungkapkan kesulitannya, kegelisahannya kepada orang tua karena ia tahu, orang tua akan membantunya mencari jalan keluar tanpa berusaha mendiktenya.

Dasar dari penyesuaian diri bagi individu adalah kesadaran akan diri dan lingkungan. Kesadaran akan 
diri mengacu pada gambaran tentang diri dan penilaian pada diri sendiri. Sedangkan kesadaran terhadap lingkungan mengacu pada persepsi individu terhadap lingkungannya baik lingkungan sosial, non sosial, fisik maupun psikologis.

Konsep diri adalah semua ide, pikiran, kepercayaan dan pendirian yang diketahui individu tentang dirinya dan mempengaruhi individu dalam berhubungan dengan orang lain (Stuart \& Sundeen, 1998: 227). Konsep diri adalah hubungan antara sikap dan keyakinan tentang diri kita sendiri (Burns,1993:63-65). Menurut Sobur, konsep diri adalah semua persepsi kita terhadap aspek diri yang meliputi aspek fisik, aspek sosial, dan aspek psikologis, yang didasarkan pada pengalaman dan interaksi kita dengan orang lain.

Menurut Djaali (2009:92), konsep diri adalah pandangan seseorang tentang dirinya sendiri yang menyangkut apa yang ia ketahui dan rasakan tentang perilakunya, isi pikiran dan perasaannya, serta bagaimana perilakunya tersebut berpengaruh terhadap orang lain.

Calhaun (1995: 72-74) mengemukakan, konsep diri adalah pandangan diri anda tentang anda sendiri yang meliputi tiga dimensi pengetahuan anda tentang diri anda sendiri, pengharapan anda mengenai diri anda, dan penilaian tentang diri anda sendiri.

Berdasarkan analisis konsep dan dan teori-teori di atas yang utamanya berkenaan dengan konsep diri, perkembangannya dan hubungannya dengan kemampuan akademis, maka dalam penelitian ini yang dimaksud dengan konsep diri adalah persepsi, gambaran dan penilaian secara menyeluruh oleh seseorang terhadap dirinya sendiri yang meliputi aspek fisik, psikis, sosial dan status akademik atau kemampuan akademik yang dimiliki.

Menurut Stuart dan Sundeen (1998: 186)ada beberapa faktorfaktor yang mempengaruhi perkembangan konsep diri. Faktorfaktor tersebut terdiri dari teori perkembangan, Significant Other (orang yang terpenting atau yang terdekat) dan Self Perception (persepsi diri sendiri).

\section{Teori Perkembangan}

Konsep diri belum ada waktu lahir, kemudian berkembang secara bertahap sejak lahir sampai mulai mengenal dan membedakan dirinya dengan orang lain. Dalam melakukan kegiatan memiliki batasan diri yang terpisah dari lingkungan dan berkembang melalui kegiatan eksplorasi lingkungan melalui bahasa, pengalaman atau pengenalan tubuh, nama pangilan, pengalaman budaya dan hubungan interpersonal, kemampuan pada area tertentu yang dinilai pada diri sendiri atau masyarakat serta aktualisasi diri dengan merealisasi potensi yang nyata.

\section{Significant Other (orang yang} terpenting atau yang terdekat)

Konsep diri dipelajari melalui kontak dan pengalaman dengan orang lain, belajar diri sendiri melalui cermin orang lain yaitu dengan cara pandangan diri merupakan interprestasi diri pandangan orang lain terhadap diri, anak sangat dipengaruhi orang yang dekat, remaja dipengaruhi oleh orang lain yang dekat dengan dirinya, pengaruh orang dekat atau orang penting sepanjang siklus hidup, pengaruh budaya dan sosialisasi. 
3. Self Perception (persepsi diri sendiri)

Persepsi individu terhadap diri sendiri dan penilaianya, serta persepsi individu terhadap pengalamannya akan situasi tertentu. Konsep diri dapat dibentuk melalui pandangan diri dan pengalaman yang positif. Sehingga konsep merupakan aspek yang kritikal dan dasar dari perilaku individu. Individu dengan konsep diri yang positif dapat berfungsi lebih efektif yang dapat dilihat dari kemampuan interpersonal, kemampuan intelektual dan penguasaan lingkungan. Sedangkan konsep diri yang negatif dapat dilihat dari hubungan individu dan sosial yang terganggu.

Dari berbagai teori di atas maka dapat dikatakan bahwa konsep diri adalah pandangan individu terhadap dirinya sendiri berupa pengetahuan diri, pengharapan diri dan penilaian diri yang meliputi diri fisik, diri etik moral, diri personal, diri keluarga, diri sosial dan kritik diri. Bagaimana individu memandang dirinya, akan mempengaruhi tingkah lakunya. Konsep diri positif maupun konsep diri negatif juga akan mengarahkan bagaimana individu bereaksi secara khas terhadap orang atau situasi serta menentukan kualitas perilakunya.

\section{Metodologi Penelitian}

Metode yang digunakan dalam penelitian ini adalah metode survei dengan pendekatan secara korelasional. Hal ini dilakukan untuk mengungkapkan hubungan antara dua variabel bebas dengan satu variabel terikat. Fakta empiris ini diperoleh melalui survei lapangan terhadap mahasiswa-mahasiswi ASM BSI di Jakarta Pusat. Penelitian ini dilaksanakan mulai dari penyebaran instrumen kuesioner perilaku lingkungan, persepsi anak terhadap pola asuh orang tua dan konsep diri berlangsung selama tiga bulan yaitu dari bulan April - Juni 2012. Tempat penelitian ini dipilih karena terbatasnya waktu dan dana yang dimiliki penulis serta letaknya yang strategis dan membuat hasil penelitian ini lebih obyektif, terwakili seluruh responden, dan mudah untuk menjangkaunya.

Sampel yang digunakan untuk uji coba dalam penelitian ini berjumlah 20 orang dan setelah uji coba, responden yang diteliti berjumlah 120 orang. Teknik pengambilan sampel yang digunakan adalah teknik simple random sampling (teknik sampel acak sederhana). Untuk pengambilan sampel sebesar 120 orang didasarkan pada Masri Singarimbun dan Sofyan Effendi (1989:162-163) yang mengatakan bahwa sampel besar yang distribusinya normal adalah sampel yang jumlahnya > 30 kasus, dan apabila analisis data yang dipakai adalah teknik korelasi maka yang harus diambil minimal 30 kasus.

dalam penelitian ini untuk mengumpulkan datam berbentuk kuesioner yang disusun oleh peneliti dan dikembangkan dalam bentuk skala Likert. Untuk memberikan batasan yang jelas dalam penyusunan instrumen, berikut dikemukakan definisi operasional dari setiap variabel yang digunakan. Setelah mengetahui hasil uji coba instrumen, bahwa data yang dihasilkan valid dan reliabel, dalam penelitian sesungguhnya dilakukan analisis data dengan pengujian- pengujian statistik. 


\section{Hasil Penelitian dan Pembahasan}

Berdasarkan hasil perhitungan (melalui SPSS) diketahui Bahwa koefisien arah regresi (b) adalah 0,219 dengan harga konstanta (a) adalah 20,448. Harga tersebut apabila dimasukkan ke dalam persamaan regresi maka diperoleh persamaan regresi $\hat{Y}=20,448+$ $0,219 \mathrm{X}_{1}$.

Dari hasil perhitungan untuk uji linieritas terhadap persamaan regresi tersebut diketahui bahwa harga $F$ sebesar 14,111. Harga ini jatuh di daerah penerimaan karena harga $F$ hitung lebih dari harga $F$ tabel untuk tingkat signifikansi 5\% (F hitung 14,111 > F tabel 1,35). Dengan demikian dapat disimpulkan bahwa hubungan yang terjadi antara variabel $\mathrm{Y}$ dengan $\mathrm{X} 1$ signifikan. Hasil perhitungan tersebut menegaskan bahwa penggunaan analisis tersebut dalam pengujian hipotesis dapat dibenarkan. Hal tersebut terdapat pada tabel 1 .

Dari tabel Analisis Varians (ANOVA) di atas dapat disimpulkan bahwa hubungan persepsi anak terhadap pola asuh orang tua $\left(\mathrm{X}_{1}\right)$ dan dengan perilaku lingkungan $(\mathrm{Y})$ adalah sangat signifikan dan linier. Output Anova menunjukkan bahwa nilai $\mathrm{F}$ hitung adalah sebesar 14.111 dengan sig 0.000. dengan demikian dapat disimpulkan bahwa Ho ditolak, atau terdapat hubungan yang signifikan antara persepsi dan perilaku. Dari persamaan regresi $\hat{Y}$ $=20,448+0,219 \mathrm{X}_{1}$ menunjukkan bahwa setiap kenaikan atau penurunan satu satuan skor persepsi anak terhadap pola asuh orang tua $\left(\mathrm{X}_{1}\right)$ akan mempengaruhi kenaikan atau penurunan satu satuan skor pada perilaku lingkungan pada mahasiswa (Y) sebesar 0,219 pada konstanta 20,448 .

\section{Tabel 1}

Perilaku Lingkungan (Y) atas Persepsi Anak terhadap Pola Asuh Orang Tua (X1)

\begin{tabular}{|c|c|c|c|c|c|c|}
\hline Model & & Sum of Squyes & Df & Mean Sourere & I & Sig. \\
\hline 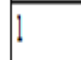 & Regreasion & 205.177 & I & 205.177 & 14.111 & $.000^{\prime}$ \\
\hline & Residual & 1715.748 & 118 & 14.540 & & \\
\hline & Total & 1920.925 & 119 & & & \\
\hline
\end{tabular}

Berdasarkan hasil perhitungan (melalui SPSS) diketahui bahwa koefisien arah regresi (b) adalah 0,500 dengan harga konstanta (a) adalah 15,367. Harga tersebut apabila dimasukkan ke dalam persamaan regresi maka diperoleh persamaan regresi $\hat{Y}=15,367+$ $0,500 \mathrm{X}_{2}$.

Dari hasil perhitungan untuk uji linieritas terhadap persamaan regresi tersebut diketahui bahwa harga $F$ sebesar 17, 529. Harga ini jatuh di daerah penerimaan karena harga $\mathrm{F}$ hitung lebih besar dari harga $\mathrm{F}$ tabel untuk tingkat signifikansi 5\% (F hitung 17, 529 > F tabel 1,35).

Dengan demikian dapat disimpulkan bahwa hubungan yang terjadi antara variabel $\mathrm{Y}$ dengan $\mathrm{X}_{2}$ signifikan. Hasil perhitungan tersebut menegaskan bahwa penggunaan analisis tersebut dalam pengujian hipotesis dapat dibenarkan. Hal tersebut dapat dilihat pada tabel 2 . 
Tabel 2

Perilaku lingkungan (Y) atas

Persepsi Anak terhadap

Pola Asuh Orang Tua(X1)

\begin{tabular}{|c|c|c|c|c|c|c|}
\hline Nodel & & Sum of Squares & Dit & Nann Soyare & I & Sire. \\
\hline & Regrasion & 2051.177 & ! & 205.177 & | 14.1111 & $1.000^{\circ}$ \\
\hline & Resioul & 1715.748 & 118 & 1.5.540 & & \\
\hline & Total & 1920.925 & 1119 & & & \\
\hline
\end{tabular}

Berdasarkan hasil perhitungan (melalui SPSS) diketahui bahwa koefisien arah regresi $b_{1}=0,139$ dan $\mathrm{b}=0,371$ dengan harga konstanta (a) adalah 13,037. Harga tersebut apabila dimasukkan ke dalam persamaan regresi maka diperoleh persamaan regresi $\hat{Y}=13,037+$ $0,139 X_{1}+0,371 X_{2}$.

Dari hasil perhitungan untuk uji linieritas terhadap persamaan regresi tersebut diketahui bahwa harga $F$ sebesar 11,485. Harga ini jatuh di daerah penerimaan karena harga $\mathrm{F}$ hitung lebih besar dari harga F tabel untuk tingkat signifikansi 5\% (F hitung 11,485 > F tabel 1,35).

Dengan demikian dapat disimpulkan bahwa hubungan yang terjadi antara variabel $\mathrm{Y}$ dengan $\mathrm{X}_{1}$ dan $\mathrm{X}_{2}$ signifikan. Hasil perhitungan tersebut menegaskan bahwa penggunaan analisis tersebut dalam pengujian hipotesis dapat dibenarkan. Hal tersebut dapat dilihat pada tabel 3 .
Tabel 3

Perilaku Lingkungan (Y) atas Persepsi Anak terhadap Pola Asuh Orang Tua $\left(\mathrm{X}_{1}\right)$ dan Konsep Diri $\left(\mathrm{X}_{2}\right)$

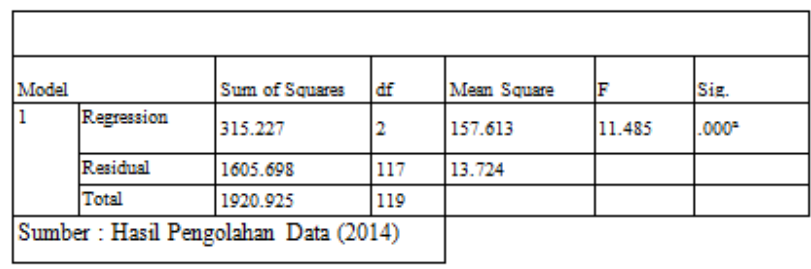

Dari tabel analisis varian (ANOVA) di atas dapat disimpulkan bahwa hubungan persepsi anak anak terhadap pola asuh orang tua $\left(\mathrm{X}_{1}\right)$ dan konsep diri $\left(\mathrm{X}_{2}\right)$ dan dengan perilaku lingkungan (Y) adalah signifikan dan linier.

Dari persamaan regresi $\hat{Y}=13,037+$ $0,139 \mathrm{X}_{1}+0,371 \mathrm{X}_{2}$ menunjukkan bahwa setiap kenaikan atau penurunan satu satuan skor Persepsi anak terhadap pola asuh $\left(\mathrm{X}_{1}\right)$ dan konsep diri $\left(\mathrm{X}_{2}\right)$ akan mempengaruhi kenaikan atau penurunan satu satuan skor pada perilaku lingkungan pada mahasiswa (Y) sebesar 0,139 dan 0,371 pada konstanta 13,037.

\section{Kesimpulan}

Berdasarkan kajian penelitian tentang hakikat persepsi anak terhadap pola asuh orang tua $\left(\mathrm{X}_{1}\right)$, konsep diri $\left(\mathrm{X}_{2}\right)$ dan perilaku lingkungan $(\mathrm{Y})$ yang telah diuraikan pada bab-bab terdahulu, dapat disimpulkan beberapa hal sebagai berikut:

1. Terdapat hubungan positif antara persepsi anak terhadap pola asuh orang tua dengan perilaku lingkungan. Artinya jika persepsi anak terhadap pola asuh orang tua makin baik, maka perilaku 
lingkungan dari anak makin meningkat.

2. Terdapat hubungan yang positif antara konsep diri dengan perilaku lingkungan mahasiswa artinya jika konsep diri makin positif, maka perilaku lingkungan dari anak makin meningkat.

3. Terdapat hubungan yang positif antara persepsi anak terhadap pola asuh orang tua dan konsep diri secara bersama-sama dengan perilaku lingkungan. Hal ini menunjukkan bahwa jika persepsi anak terhadap pola asuh orang tua dan konsep diri makin positif, maka perilaku lingkungan dari anak makin baik.

4. Persepsi anak terhadap pola asuh orang tua dan konsep diri sangat erat kaitannya dengan perilaku lingkungan pada mahasiswa. Atau dengan kata lain perilaku lingkungan sangat ditentukan oleh persepsi anak terhadap pola asuh orang tua dan konsep diri. Hal ini terlihat dari kontribusi masingmasing variabel bebas terhadap variabel terikat sebagai berikut:

a. Persepsi anak terhadap pola asuh orang tua memberikan kontribusi $\quad 32,7 \%$ terhadap perilaku lingkungan.

b. Konsep diri memberikan kontribusi $36 \%$ terhadap perilaku lingkungan.

c. Persepsi anak terhadap pola asuh orang tua dan konsep diri secara bersamasama memberikan kontribusi 25,3 \% terhadap perilaku lingkungan.

\section{Daftar Pustaka}

Bloom, Benyamin S. 1981. Taxonomy of Educational Objectives, Book I: Cognitive Domain, London : Longman Group Ltd.

Chiras , Daniel D. 1988. Environmental Science: A Framework for Decision Making, California: The Benjamin Cummings Publishing Company, Inc.

Clark L.Hull. 1943. Principles of Behavior. New York: Appleton-Century-Crofts.

Darajat, Zakiyah. 1996. Ilmu Jiwa Agama. Jakarta: Bulan Bintang.

Davidoff. 1998. Psikologi Suatu Pengantar. Jakarta: Erlangga.

Djaali. 2009. Psikologi Pendidikan. Jakarta: Bumi Aksara.

Hayati, Sri. 2001. Pemahaman Konsep Ekologis Global pada Siswa SD di Kota Bandung. Bandung: Lemlit-UPI.

Irwanto, dkk. 1991. Kepribadian Keluarga Narkotika. Jakarta: Arcan.

J. Rakhmat. 2001. Psikologi Komunikasi. Edisi Revisi. Bandung: PT. Remaja Rosdakarya.

James F. Calhaun dan Joan Ross Acocella. 1995. Psikologi Tentang Penyesuaian dan Hubungan

Kemanusiaan, terjemahan Sarmoko. Semarang, IKIP Semarang. 
Mohamad, Soerjani.1997. Pembangunan dan Lingkungan: Meniti Gagasan dan Pelaksanaan Sustainable Development. Jakarta: IPPL.

R.B. Burns. 1993. Konsep Diri: Teori, Pengukuran, Perkembangan dan Perilaku, alih bahasa Eddy. Jakarta: Arcan.

Singarimbun, Masri dan Sofyan Effendi. 1989. Metode Penelitian Survei Jakarta : LP3ES

Soemarwoto, Otto. 1992. Indonesia dalam Kancah Isu Lingkungan Global. Jakarta: Gramedia.

Stenberg, Robert J. 2008. Psikologi Kognitif (Edisi keempat), diterjemahkan oleh Yadi Santoso. Jakarta: Pustaka Pelajar.

Stuart and Sundeen S.J. 1998. Principles and Practice of phychiatric nursing. Sixth edition. St.Louis Mosby Year Book.

TIM Penyusun Kamus Pusat Pembinaan dan Pengembangan Bahasa. 1998. Kamus Besar Bahasa Indonesia. Jakarta: Balai Pustaka.

Walgito,Bimo.1994.Psikologi

Sosial.Yogyakarta:Andi Offset 
